\title{
Enzymatic determination of $1{ }^{14} \mathrm{C}$-glucose in pig plasma
}

\author{
L. Schäffer and B.Tronier \\ Novo Research Institute, Copenhagen, Denmark
}

\begin{abstract}
Summary. A simple and cheap one-step enzymatic method has been developed for the determination of $1-{ }^{14} \mathrm{C}$-glucose in plasma. C-1 of glucose is cleaved off as $\mathrm{CO}_{2}$ by treatment with hexokinase, glucose-6-phosphate dehydrogenase, and 6-phosphogluconic dehydrogenase. True $1{ }^{14} \mathrm{C}$-glucose activity is then calculated as the difference between total radioactivity and radioactivity remaining after enzyme treatment and evaporation. The reaction is shown to be quantitative and specific,
\end{abstract}

thus eliminating both labelled metabolites and label recycled to other positions in glucose. Two different types of pig experiments show that $1-{ }^{14} \mathrm{C}$-glucose, when determined by this method, is as irreversible a tracer as the commonly used $3-{ }^{3} \mathrm{H}$ glucose.

Key words: $1 \cdot{ }^{14} \mathrm{C}$-glucose, enzymatic assay, glucose tracers.
Using $1-{ }^{14} \mathrm{C}$-glucose as a tracer in metabolic studies has the drawback that labelled metabolites and label recycled into glucose accumulate in plasma during the experiment and must be removed to obtain satisfactors results. This has previously been achieved by various combinations of ion exchange chromatography, enzyme reactions, and traditional organic chemistry [1-2]. This procedure is quite tedious, and in double tracer experiments such as measurement of endogenous glucose production during a glucose tolerance test where specific information about metabolites and recycling is not required, it would be useful to have a simpler method of determining $1-{ }^{14} \mathrm{C}$-glucose. We therefore undertook the development of a one-step enzymatic assay.

\section{Materials and methods}

\section{Materials}

Hexokinae (H 5375), glucose-6-phosphate dehydrogenase ( $\mathrm{Ga} 4134$ ), 6-phosphogluconic dehydrogenase (P 0507), L-glutamic dehydrogenase (G 4387), $\alpha$-ketoglutaric acid (K 1750), ATP (A 6144), NADP (N 0505), and the $\mathrm{Ba}(\mathrm{OH})_{2}$-solution were obtained from Sigma Chemical Co. (St.Louis, Mo., USA). U $-{ }^{14} \mathrm{C}$-glucose, U- ${ }^{14} \mathrm{C}$-lactic acid, and $\mathrm{U}-^{14} \mathrm{C}$-alanine were obtained from Amersham International (Amersham, Bucks, UK), $3-{ }^{3} \mathrm{H}$-glucose was from New England Nuclear Products (Boston, Mass., USA), and $1{ }^{14} \mathrm{C}$-glucose was obtained either from Amersham or from New England Nuclear. The scintillation liquid used was Opti-Fluor (Packard Instrument BV, Groningen,
The Netherlands). All samples were counted in a Packard 1500 Liquid Scintillation Analyser.

\section{Sample treatment}

One $\mathrm{ml}$ of plasma was deproteinized by the addition of $2 \mathrm{ml}$ of water, $1.5 \mathrm{ml}$ of $0.6 \mathrm{~mol} / 1 \mathrm{Ba}(\mathrm{OH})_{2}$, and $1.5 \mathrm{ml}$ of $0.6 \mathrm{~mol} / 1 \mathrm{ZnSO}_{4}$, followed by centrifugation. Two $1 \mathrm{ml}$ aliquots of the centrifugate were placed in scintillation vials, evaporated to dryness under a stream of air, redissolved in $0.5 \mathrm{ml}$ of water and counted after the addition of $10 \mathrm{ml}$ of scintillation liquid. To each of another two $1 \mathrm{ml}$ aliquots was added $0.5 \mathrm{ml}$ of a freshly made solution containing $0.08 \mathrm{~mol} / 1$ phosphate, $0.05 \mathrm{~mol} / 1 \mathrm{NH}_{4}{ }^{+}, 0.01 \mathrm{~mol} / 1 \mathrm{Mg}^{++}, 100 \mathrm{mg} / 1 \mathrm{NaN}_{3}, 10 \mathrm{~g} / \mathrm{l}$ a-ketoglutaric acid, $6 \mathrm{~g} / 1 \mathrm{ATP}, 1 \mathrm{~g} / 1 \mathrm{NADP}, 4000 \mathrm{U} / 1$ hexokinase, $800 \mathrm{U} / 1$ L-glutamic dehydrogenase, $400 \mathrm{U} / 1$ glucose- 6 -phosphate dehydrogenase, $200 \mathrm{U} / 1$ 6-phosphogluconic dehydrogenase, final $\mathrm{pH}=7.0$.

The mixture was incubated in a scintillation vial for $18 \mathrm{~h}$ at $37^{\circ} \mathrm{C}$, acidified with $0.5 \mathrm{ml} 1 \mathrm{~mol} / 1$ acetic acid, evaporated to dryness, and

Table 1. Radioactivity remaining after enzyme treatment

\begin{tabular}{|c|c|}
\hline tracer & $\%$ remaining $\pm \mathrm{SD}$ \\
\hline $1-{ }^{14} \mathrm{C}-$ glucose $\mathrm{e}^{\mathrm{a}}$ & $1.4 \pm 0.1(n=10)$ \\
\hline $1{ }^{14} \mathrm{C}-$ glucose $\mathrm{e}^{\mathrm{a}}$ & $2.0 \pm 0.1(n=10)$ \\
\hline $1-{ }^{14} \mathrm{C}-$ glucose $\mathrm{e}^{\mathrm{a}}$ & $4.0 \pm 0.3(n=10)$ \\
\hline $\mathrm{U}-{ }^{14} \mathrm{C}$-glucose & $84.5 \pm 0.6(n=3)$ \\
\hline $3-{ }^{3} \mathrm{H}$-glucose & $>99(n=10)$ \\
\hline U- ${ }^{14}$ C-lactate & $>99(n=5)$ \\
\hline $\mathrm{U}-{ }^{14} \mathrm{C}$-alanine & $>99(n=5)$ \\
\hline
\end{tabular}

a three different batches 


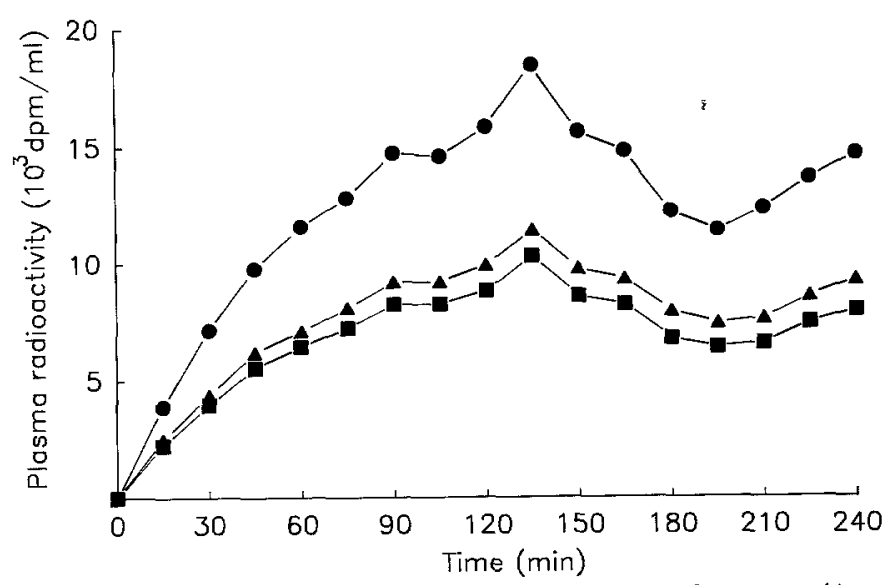

Fig. 1. Tracer profiles during a constant infusion of $3-{ }^{3} \mathrm{H}$ - and $1-{ }^{14} \mathrm{C}$ glucose, with cold glucose being infused between 120 and $180 \mathrm{~min}$. Closed circles, ${ }^{3} \mathrm{H}$-activity; triangles, total ${ }^{14} \mathrm{C}$-activity; squares, $1-{ }^{14} \mathrm{C}$ glucose activity

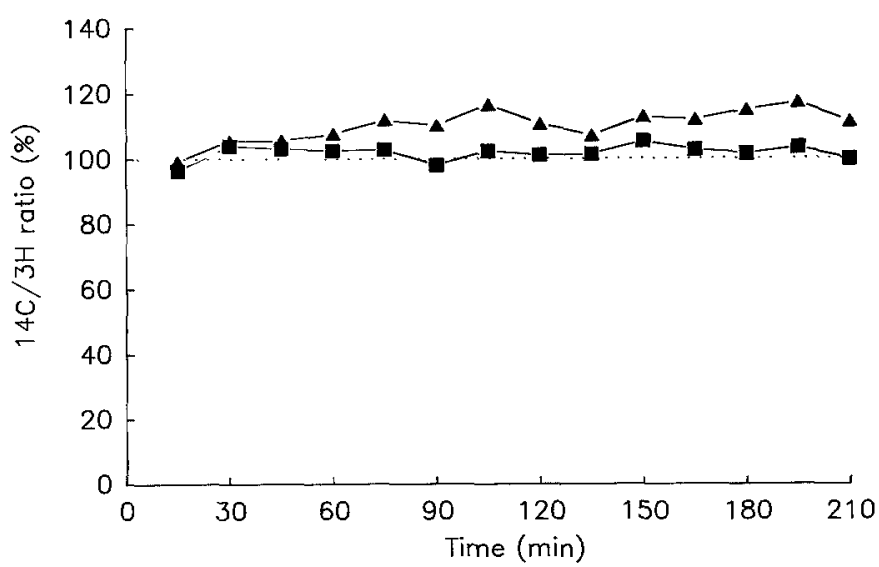

Fig. 2. Ratio between ${ }^{14} \mathrm{C}$-activity and ${ }^{3} \mathrm{H}$-activity expressed relative to the ratio in the infusate. Triangles, total ${ }^{14} \mathrm{C}$-activity; squares, corrected ${ }^{14} \mathrm{C}$-activity

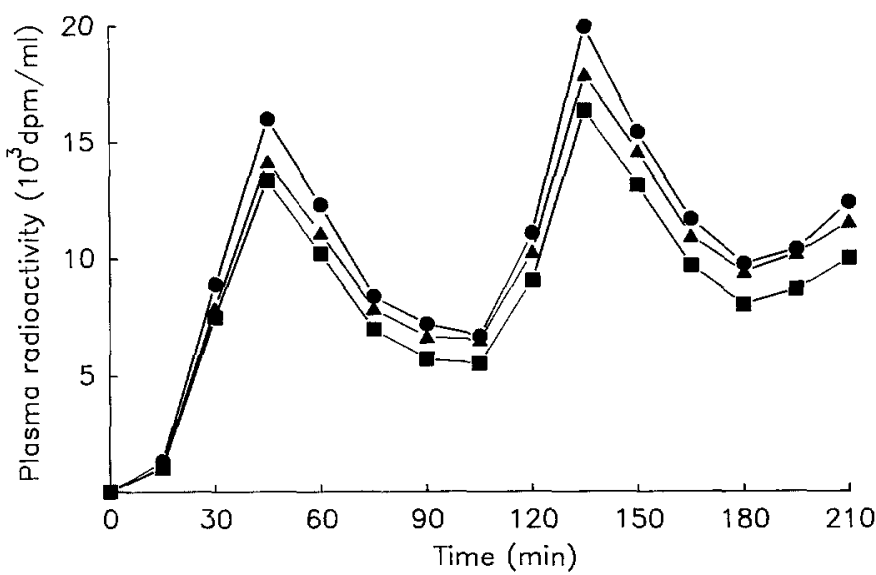

Fig. 3. Tracer profiles after a gastric load of glucose labelled with $3-{ }^{3} \mathrm{H}$ - and $1{ }^{14} \mathrm{C}$-glucose. Closed circles, ${ }^{3} \mathrm{H}$-activity; triangles, total ${ }^{14} \mathrm{C}$-activity; squares, $1{ }^{14} \mathrm{C}$-glucose activity

counted after the addition of $0.5 \mathrm{ml}$ of water and $10 \mathrm{ml}$ of scintillation liquid. Control samples of plasma with $1{ }^{14} \mathrm{C}$-glucose added were included with each assay. True $1{ }^{14} \mathrm{C}$-glucose activity was calculated as the difference between total ${ }^{14} \mathrm{C}$-radioactivity and ${ }^{14} \mathrm{C}$-radioactivity remaining after the enzyme treatment.

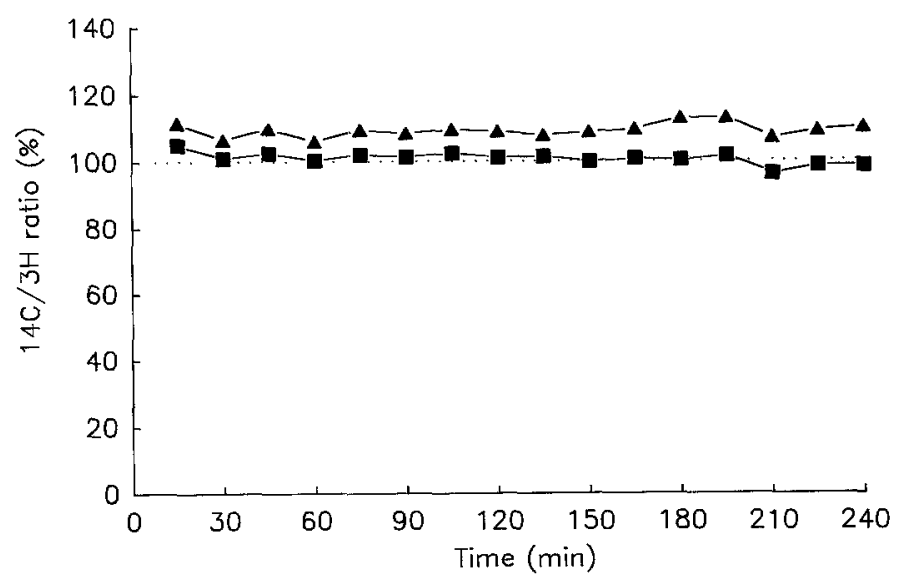

Fig.4. Ratio between ${ }^{14} \mathrm{C}$-activity and ${ }^{3} \mathrm{H}$-activity expressed relative to the ratio in the gastric load. Triangles, total ${ }^{14} \mathrm{C}$-activity; squares, corrected ${ }^{14} \mathrm{C}$-activity

\section{Validation}

To check the specificity of the method, plasma samples with added $\mathrm{U}-{ }^{14} \mathrm{C}$-lactate, $\mathrm{U}^{14} \mathrm{C}$-alanine, and $\mathrm{U}_{-}{ }^{14} \mathrm{C}$-glucose were subjected to the enzyme treatment. Also, a dilution series of $1{ }^{14} \mathrm{C}$-glucose in pig plasma with activities of 3000 to $3.6 \cdot 10^{6} \mathrm{dpm} / \mathrm{ml}$ (11 different levels) was analysed in triplicate (each sample counted in duplicate) and the precision of the assay was calculated.

\section{Pig experiments}

A $40 \mathrm{~kg}$ pig (Danish Landrace) was used. Catheters were inserted in the common carotid artery, in the jugular vein, and in the stomach.

In one experiment a mixture of $3-{ }^{3} \mathrm{H}$-glucose and $1{ }^{14} \mathrm{C}$-glucose was infused in the jugular vein at a constant rate for $4 \mathrm{~h}$. An infusion of cold glucose $(0.4 \mathrm{~g} / \mathrm{min})$ into the jugular vein was initiated after $2 \mathrm{~h}$ and stopped after $3 \mathrm{~h}$. Blood was sampled from the carotid artery at $15 \mathrm{~min}$ intervals for $4 \mathrm{~h}$.

In another experiment $40 \mathrm{~g}$ of glucose labelled with $3{ }^{3} \mathrm{H}$-glucose and $1{ }^{14} \mathrm{C}$-glucose was placed in the stomach of the pig and blood was sampled from the caroticl artery at $15 \mathrm{~min}$ intervals for $3.5 \mathrm{~h}$. In both experiments blood was collected in cold NaF-tubes and centrifuged immediately.

\section{Results}

Table 1 shows the percentage of label remaining after enzyme treatment of various tracers added to plasma. When a dilution series of $1-{ }^{14} \mathrm{C}$-glucose in plasma was analysed in triplicate the average coefficient of variation $(\mathrm{CV})$ of total ${ }^{14} \mathrm{C}$-activity was $0.78 \%$ (range $0.53-1.37$ ), the average $\mathrm{CV}$ of the correction was $4.3 \%$ (range $0.86-13.4$ ) and the average $\mathrm{CV}$ of the calculated true $1-{ }^{14} \mathrm{C}$-glucose values was $0.68 \%$ (range $0.28-1.10$ ). CV's of $>5 \%$ were only obtained in correction samples with activities of $<100 \mathrm{dpm}$ and since the correction for this particular tracer batch amounted to $4.08 \pm 0.07 \%$ of the total radioactivity, no effect was seen on the CV's of the calculated true $1-{ }^{14} \mathrm{C}$-glucose values.

The decarboxylation of glucose is quantitative for plasma samples containing up to $20 \mathrm{mmol} / \mathrm{l}$ glucose and the range can be extended by increasing the amount of ATP in the reaction mixture.

Figures 1 and 3 show the plasma tracer profiles in the two pig experiments and Figs. 2 and 4 show the ratio between the ${ }^{14} \mathrm{C}$ - and the ${ }^{3} \mathrm{H}$-activity in plasma, expressed relative to the ratio between the specific activities in the infusate/gastric load. 


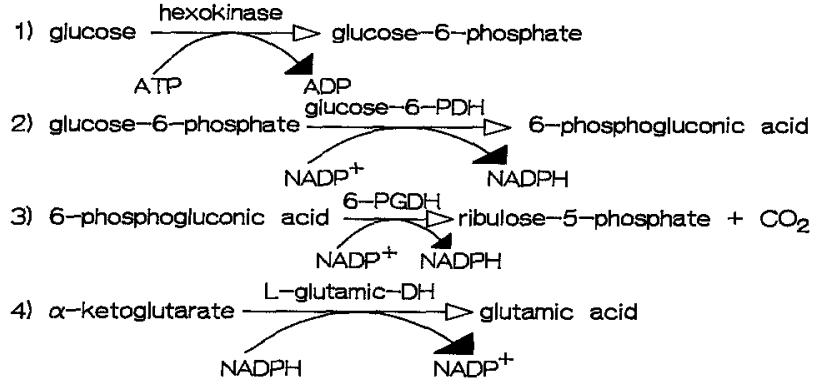

reactions 1-3 decarboxylate glucose, reaction 4 regenerates NADP ${ }^{+}$ Fig.5. Reaction scheme for the enzymatic decarboxylation of glucose

\section{Discussion}

The method described above is a simplified variation of a method used by Kalhan [3] to determine recycling of glucose. The enzyme treatment selectively removes all radioactivity present in the 1-position of glucose by the reaction sequence shown in Figure 5. The earlier applications of the method involved collection and determination of the evolved labelled $\mathrm{CO}_{2}$ whereas in our method samples are just evaporated. The radioactivity remaining after enzyme treatment and evaporation represents labelled metabolites, label recycled to other positions in glucose, and impurities in the $1-{ }^{14} \mathrm{C}$-glucose, and is subtracted from total radioactivity to give true $1{ }^{14} \mathrm{C}$-glucose. Thus, the correction obtained by this method is a minimum estimate of the true correction since it does not reflect recycling to the 1-position. Also, it is conceivable that some minor metabolites could be oxidized by the enzyme system (or by impurities in the enzymes), but as the major metabolites lactate and alanine were found not to be oxidized at all this is probably not an important source of error. The specificity of the enzyme system was further confirmed by the fact that $1 / 6$ of $\mathrm{U}^{14} \mathrm{C}$-glucose was oxidized. The nonoxidized fraction of the three batches of $1-{ }^{14} \mathrm{C}$-glucose used was $1.4 \%, 2.0 \%$, and $4.0 \%$, respectively. This fraction was constant for each batch and independent of the glucose concentration, suggesting that it represents an impurity in the tracer rather than an imcomplete reaction. The ${ }^{3} \mathrm{H}$-activity of samples containing $3-{ }^{3} \mathrm{H}-$ glucose remains constant during the enzyme treatment which reflects the fact that the hydrogen atom in posi- tion 3 of glucose is transferred to $\mathrm{NADP}^{+}$in the decarboxylation step and from there incorporated into L-glutamic acid in the $\mathrm{NADP}^{+}$-regenerating step rather than being lost as water [4].

To illustrate the usefulness of this method we performed two pig experiments with glucose labelled with both $3-{ }^{3} \mathrm{H}$-glucose and $1-{ }^{14} \mathrm{C}$-glucose. These experiments were designed to represent two commonly used tracer techniques. In both experiments the ratio between corrected ${ }^{14} \mathrm{C}$-activity and ${ }^{3} \mathrm{H}$-activity in plasma was constant and equal to that of the tracer mixture, indicating that $1{ }^{14} \mathrm{C}$-glucose, when determined by this method, is as irreversible a tracer as $3-{ }^{3} \mathrm{H}$-glucose [1]. This should be quite useful in metabolic studies using double tracer techniques. The difference between total radioactivity and true $1-{ }^{14} \mathrm{C}$-glucose radioactivity increases slowly to about $15 \%$ during each experiment, which is in agreement with an expected increase in recycled radioactivity. In conclusion, the method described here is a cheap, easy, and reliable way of measuring true $1{ }^{14} \mathrm{C}$-glucose activity in plasma in the presence of labelled metabolites and label recycled to other positions than the 1-position.

\section{References}

1. Ferrannini E, Del Prato S, Defronzo RA (1987) Glucose kinetics. Tracer methods. In: Clarke WL, Larner J, Pohl SL (eds) Methods in diabetes research, Vol 2. Wiley, New York, pp 107-141

2. Reichard GA, Moury NF, Hochella NJ, Patterson AL, Weinhouse S (1963) Quantitative estimation of the Cori cycle in the human. J Biol Chem 238: 495-501

3. Kalhan SC, Savin SM, Adam PAJ (1977) Estimation of glucose turnover with stable tracer glucose-1-13 C. J Lab Clin Med 89: 285-294

4. Popják G (1970) Stereospecificity of enzymic reactions. In: Boyer PD (ed) The Enzymes, Vol 2. Academic Press, New York London, pp 115-215

Received: 23 March 1989

and in revised form: 2 June 1989

Dr. L. Schäffer

Department of Clinical Chemistry

Novo Research Institute

Novo Alle

DK-2880 Bagsvaerd

Denmark 